\title{
Enterprise Income Tax Evasion from Real Estate Transfer Activities in Vietnam and Recommendations
}

\author{
Ngo Thi Hong Anh \\ Thai Nguyen University of Technology, Thai Nguyen University, Vietnam
}

\begin{abstract}
The research is supported by Thai Nguyen University of Technology, Thai Nguyen University, Vietnam.
Abstract

The current laws on land, investment, business, real estate, taxation and other relevant laws in Vietnam are still not tight and inappropriate, and also contain many loopholes. As a result, many businesses have real estate transfer activities, but tax evasion in many forms and ways causes great loss to the state budget, affecting the business environment and bad impacts on the current socio-economic-political situation in Vietnam. From the author's study on Vietnam's legal regulations, based on analysis, comparison, aggregation from statistical data, specific studies of some hypothetical cases are made to see the legal loopholes that businesses Vietnam takes advantage to avoid tax. It is common to observe that the methods used by many businesses including: performing tricks to minimize taxable income directly from real estate transfers, making fraudulent transactions that conceal real estate transfer contracts, taking advantage of the law on reorganization of enterprises and tax policies to separate enterprises for real estate transfer, transferring of shares to avoid tax, or colluding with competent state agencies on the investment, environmental resources, and tax to avoid corporate income tax. From there, the author proposes the recommendations to improve the law on land, taxes and other relevant legal documents.
\end{abstract}

Keywords: law, real estate transfer, corporate income tax, tax evasion

DOI: $10.7176 / \mathrm{JLPG} / 95-04$

Publication date:March $31^{\text {st }} 2020$

\section{Introduction}

Taxes are a major revenue source of the state budget, and the tax of the state is an effective tool to regulate income and meet the needs of state budget spending and macro-economic management. The current tax system of Vietnam is mainly based on income (individuals, businesses), the use of income (added value, special sales, import and export), or the levy on assets (such as environmental protection tax, agricultural land use, non-agricultural land, royalties, license tax), in which corporate income tax accounts for the majority of tax revenue and significantly contributes to total state budget revenues.

According to statistics on December 31, 2018 in Vietnam, there are 714,755 active businesses [1]. The ratio of income from corporate income tax (excluding crude oil) to the total state budget revenue in the 2006-2010 period averages from 15.41\%. From 2011 to 2015, it increased to $16.11 \%$. In the 3 years from 2016 to 2018, the ratio of income from corporate income tax (excluding crude oil) to the total state budget revenue accounted for about $14.86 \%$ [2]. In fact, real estate transfer activities take place vibrantly throughout the provinces and cities of the country by many businesses (real estate business or not), however the corporate income tax collected from the operation This is very limited, according to the statistics of the 1,000 largest corporate income taxpayers in 2018 accounting for $60.3 \%$ of the total state budget revenue on corporate income tax, the real estate only accounts for about $10.74 \%$ [3].

\section{Corporate income tax from real estate transfer}

According to the Law on Corporate Income Tax 2008 amended and supplemented in 2013 and 2014, the enterprises earning incomes from producing and trading activities of goods and services as well as other incomes are subject to corporate income tax. In particular, the income from real estate transfer activities must be determined separately for tax declaration and payment [4].

Payable amount of corporate income tax $=$ Assessable income from real estate transfer $\times$ Tax rate of $20 \%$ where:

$$
\begin{gathered}
\text { Taxable income }=\text { Income taxes }- \text { Real estate transfer losses of previous years } \\
\text { (if any) }
\end{gathered}
$$

If an enterprise in a tax period has real estate transfer activities, such losses are offset against profits from production and business activities (including other incomes specified in Article No.7 of Circular No.78).

Income taxes $=$ Revenue earned from real estate transfer activities - The cost of real estate and deductible expenses related to real estate transfer

Turnover from real estate transfer activities is determined according to the real price of real estate transfer under transfer and sale contracts in accordance with law (including surcharges and additional charges if any). For the manufacturing, trading, and service businesses, the goal is to maximize profits and minimize costs and taxes and fees. Therefore, if there is a transfer of real estate and income, even a huge profit, the enterprise will implement 
many ways to legalize accounting records and files so that they do not have income or get very little income from this activity to deal with tax authorities and tax evasion. Accordingly, what is the cause of the loss of corporate income tax? What is the solution to increase the state budget revenue with the tool of corporate income tax from the real estate transfer activities today?

\section{Objectives and Methods}

\subsection{Objectives}

- Research on the legal regulations of corporate income tax from real estate transfer in Vietnam.

- Research some techniques to evade corporate income tax from real estate transfer activities of Vietnamese enterprises today.

- Suggest the legal recommendations to promptly amend and supplement relevant laws to ensure the effectiveness of the legal system and feasibility, which contribute to a healthy business environment and guarantee the revenue for the state budget for real estate transfer activities of enterprises today.

\subsection{Method}

- Methods of analyzing, comparing jurisprudence, and synthesizing legal sciences are used for setting out common presumptive situations that enterprises can make to evade taxes.

\section{Actual situation of corporate income tax evasion from real estate transfer activities}

\subsection{Minimization of taxable income direct from real estate transfers}

From the above-mentioned provisions on the calculation of enterprise income tax for real estate transfer, businesses pay attention on 3 factors to avoid paying or pay less tax:

First, reduction or exemption from the tax rate of 20\%: Enterprises engaged in real estate transfer shall seek ways to qualify for tax incentives, exemption or reduction of tax rates as prescribed in Articles No.13, 14 and 15 of the Law on Enterprise Income Tax.

Second, loss carry forward: Enterprises with losses from real estate transfer activities are entitled to carry forward losses for a period of 5 years, so they may formulate a roadmap for real estate transfer activities so that they do not have taxable income and tax evasion.

Third, pushing up the cost of real estate and deducting expenses related to real estate transfer activities not to have taxable income: Suppose that the enterprise B buys real estate at high price and sells it at low price. Example: Mr. A transfers a land plot of $1000 \mathrm{~m}^{2}$ of non-agricultural land to the enterprise B for 20 billion VND. Then, the enterprise B sells to the enterprise C for 30 billion VND. Normally, with the above transaction, B will have to pay the amount of enterprise income tax: 30 billion VND -20 billion VND $=10$ billion VND $* 20 \%=2$ billion VND.

However, B may negotiate a transfer price higher than the actual one on the contract with A for 30 billion, so the enterprise B will pay the difference in personal income tax to Mr. A, even though the price bracket of the provincial People's Committee having the land for the above land area is 10 billion VND. In this case, the total personal income tax paid by Enterprise $\mathrm{B}$ on behalf of $\mathrm{A}$ is: 10 billion VND $* 2 \%=200$ million VND [5]. Accordingly, the amount of corporate income tax that B escaped is 2 billion VND - 200 million VND $=1.8$ billion VND.

In addition, the common act of real estate enterprises during transferring is the situation of recording two prices [6]: the real transfer price and the price recorded on invoices, vouchers and books. In fact, businesses record invoice prices that are usually only a half, even one-third of the actual transfer price and are accepted by the assignee. The remaining amount will usually be accounted as the service fee.

For example, P Joint Stock Company is assigned to execute an investment project to build a complex of trade fair and trade center in the construction industry combined with high-class housing area of about 12 hectares and land area and houses for sale of about 7.5 hectares, and the form of land allocation has land use levy. Assuming P JSC transfers $100 \mathrm{~m}^{2}$ of land to $\mathrm{Mr}$. L with the actual transfer price of 1.2 billion VND. However, in the contract and invoice, the parties agreed to record 600 million VND (including corporate income tax), so the remaining amount of 600 million VND must not be accounted, declared and paid to corporate income tax. Hence, if calculating the corporate income tax of 6 million $/ \mathrm{m}^{2} * 7.5$ ha $* 20 \%$, the revenue loss for the budget is not small.

In another case, Enterprise $\mathrm{T}$ is the investor that is assigned land with collection of land use fees to invest in infrastructure of the urban area and signs a contract with DX enterprise, whereby the enterprise DX exclusively distributes TL urban area project with 1000 lots on the market. In fact, the enterprise DX stands out as an intermediary to place orders for customers, and the transfer value is about 500 million VND/ lot. However, DX makes orders with customers with two prices including the transfer price of 300 million VND/ lot and service fee of 200 million VND/ lot. Therefore, the amount of 200 million VND / lot * 1000 lots $* 20 \%$ is not allowed to be calculated for enterprise income tax up to 40 billion VND. 
3.2. Real estate transfer covered up by capital contribution contracts, loan contracts, business cooperation contracts to avoid tax

In case of contributing capital with land use rights to become owners of limited liability companies, shareholders of joint-stock companies, and partnerships or contributing capital to business cooperation, there is no need to pay enterprise income tax and registration fee [7].

In fact, many businesses have real estate transfer activities but cover up other contract forms such as capital contribution contracts, loan contracts, and business cooperation contracts. However, they are transfer contracts of land use rights, so the competent state authority un-controls the purchase and sale of real estate resulting in tax losses.

\subsection{Real estate transfer covered up in the form of splitting the company and transferring shares to avoid taxes} Under the current Vietnamese law, for a limited liability company, a new member may be added to cover up the transfer of real estate [8], combined with the separation of public assets [9], or registration with a business registration agency to complete the transfer of real estate without carrying out procedures for transfer of land use rights and evading corporate income tax [10], while the current law has not provided to control [11].

For a joint-stock company, similar to the aforementioned limited liability company, it is possible to separate a company into a new joint-stock company, from which the transfer of an individual's shares is used to transfer real estate and avoid corporate income tax.

According to current regulations, for the share transfer activities of unlisted joint stock companies, the taxable income is determined as the one-time transfer price and the payable personal income tax are determined as follows [12]:

Payable income tax of individuals $=$ Securities transfer price each time $\times$ Tax rate of $0.1 \%$

The securities transfer price is determined to be the price stated in the transfer contract or the actual transfer price according to the accounting books of the unit that has transferred securities at the time of making the latest financial statement as prescribed of the accounting law before the time of transfer.

Suppose that T\&T Joint Stock Company with 5 members including P, Q, X, Y, Z in 2019 won the land auction with the worth of 50 billion VND and the actual price increased to 100 billion VND to sell it to A\&A Company. T\&T splits the company and establishes T\&A Joint Stock Company by transferring that land to T\&A with individual shareholders $\mathrm{P}, \mathrm{Q}$ and $\mathrm{X}$. After that, $\mathrm{P}$ and $\mathrm{Q}$ transferred their shares, which are the value of that land use right for A with a tax rate of $0.1 \%$, about 100 million VND. Meanwhile, if the transfer between T\&T and A\&A will be taxed at 50 billion VND $* 20 \%=10$ billion VND.

While some other countries in the world control the separation of companies to transfer assets to avoid tax, Vietnam has not specified. For example, Japanese law specifies the standard case of company separation (between 2 companies in a parent-child relationship; a company holding more than $50 \%$ of the shares of the separated company; two companies having the same business line) is not required to pay tax, and the non-standard split case, in which there is a transfer of land or securities, the separated company is obliged to pay property transfer tax [13].

3.4. Collaborating with the competent authority to avoid corporate income tax from the transfer of land use rights In fact, because real estate transfer procedures, especially the transfer of investment projects between businesses, is quite complicated, instead of the parties carrying out procedures for land use right transfer or project transfer with a tax rate of $20 \%$, the parties with the support of the agency competent to manage land and project management coordinate for the seller to return the assigned land with payment. The rent is paid for the entire tenancy, and the buyer is the owner of the land in the form of previous land use and avoids corporate income tax.

\section{Discussion}

Currently, the annual land price list of the provincial People's Committee is not suitable with the reality, because there is often a big difference and much lower than the market price [14], which makes the basis for calculating the business income tax unsecured, leading to the loss of corporate income tax. Therefore, it is necessary to set land prices that are suitable and close to reality, and the activities of independent and objective land valuation must be improved. Moreover, strict sanctions on acts of making prices higher or lower than transfer prices should be specified and added.

The laws on land, businesses, real estate business, investment, even banks and taxes are needed to amend, supplement and stricter regulate to ensure control of loan transactions, capital contribution, business cooperation but actually transfer of the enterprise's land use right to other organizations and individuals. In order to avoid loss of state assets, the strict sanctions for acts of making fake transactions to evade taxes should be provided, the activities of inspection and examination as well as the tax officials must be strengthened.

It is necessary to have close coordination and cooperation between the land management agencies, business registration offices, tax agencies and other relevant agencies in the enterprise division, splitting, capital contribution and business cooperation activities, which has changed land users but actually by passed the law to 
avoid tax, and so on. The reform administrative procedures should be continued to remove ask-give mechanism and gradually shift to the form of administrative service. On the other hand, the inspection and examination must be enhanced to prevent acts of corruption from civil servants related to the transfer of land use rights of enterprises, ensuring that the law is effective and feasible in reality.

It is necessary to publicize all processes and conditions when performing state management activities on land, bidding, and auction on the mass media, ensuring transparency, equality and effect in practice. All information on land and related issues needs to increase publicity, transparency and effective implementation of the national electronic information system.

It is necessary to replace the regulation on corporate income tax from real estate transfer with the annual tax on real estate value [15]. Since then, businesses holding real estate will have to pay real estate taxes and eliminate the tax evasion acts.

\section{Conclusion}

In this paper, the law on corporate income tax from real estate transfer of Vietnamese businesses is studied to offer some tricks in many ways to avoid taxes or tax evasion of enterprises having real estate transfer activities. It also reveals that the provisions of laws on land, enterprises, real estate investment and business, taxes and other relevant are still many loopholes and no or lax sanction, which lead to the phenomenon of "circumventing the law" and "avoiding taxes". There has not been a connection between agencies: business registration, land, construction and related agencies in controlling real estate transfer activities covered with other fake transactions. Consequently, businesses having transfer real estate make a profit of a huge amount of tax, so the state budget lost significantly due to negative phenomena, corruption, group interests between enterprises and competent officials and officials in land management agencies, project management. It makes negative impacts on investment environment and competitiveness of Vietnam in the process of international economic integration.

Some solutions to improve the laws on land, investment, businesses, real estate business, and taxes are proposed to help improve business environment, clean up the legal relations on land for businesses, and meet business needs, requirements of international economic integration, as well as the improvement of competitiveness and equality, transparency and effective management of state land resources.

In the future work, the provisions of Vietnamese laws on corporate income tax from real estate transfer activities have been made to compare to those of other countries. The tax avoidance of businesses in the world today will be discussed.

\section{Acknowledgment}

The work presented in this paper is supported by Thai Nguyen University of Technology, Thai Nguyen University, Vietnam.

\section{References}

[1] https://www.gso.gov.vn/default.aspx?tabid=406\&idmid=6\&ItemID=19273

[2]https://www.mof.gov.vn/webcenter/portal/tttc/r/o/nctd/nctd_chitiet?dDocName=MOFUCM153854\&_afrLoop= 56871199054454726\#!\%40\%40\%3F_afrLoop\%3D56871199054454726\%26dDocName\%3DMOFUCM1538 54\%26_adf.ctrl-state\%3D4nasaojde_50

[3]https://thoibaonganhang.vn/cong-bo-xep-hang-1000-doanh-nghiep-nop-thue-tndn-lon-nhat-2018-93172.html

[4] Clause 2, Article 3; Clause 3, Article 7 of the Law on Corporate Income Tax No. 14/2008/QH12 dated June 3, 2008 of the National Assembly of Vietnam (amended and supplemented in 2013; 2014).

[5] Clause 2, Article 23 of the Law on Personal Income Tax No. 04/2007/QH12 dated November 21, 2007 of the National Assembly of Vietnam (amended and supplemented in 2012).

[6] Nguyen Thi Hong Nhung (2012). Legislation on the transfer of land use rights in real estate business in Vietnam, Hanoi Law University, p.155.

[7] Point a, Clause 1 Article 36 of the Law on Enterprises No. 68/2014/QH13 dated November 26, 2014 of the National Assembly of Vietnam.

[8] Point b, Clause 1, Article 68 of the Law on Enterprises No. 68/2014/QH13 dated November 26, 2014 of the National Assembly of Vietnam.

[9] Clause 1, Article 193 of the Law on Enterprises No. 68/2014 / QH13 dated November 26, 2014 of the National Assembly of Vietnam.

[10] Point m, Clause 1, Article 169 of Law on Land No. 45/2013/QH13 dated November 29, 2013 of the National Assembly of Vietnam (amended and supplemented in 2018).

[11] Article 3 of the Law on Corporate Income Tax No. 14/2008/QH12 dated June 3, 2008 of the National Assembly of Vietnam (amended and supplemented in 2013; 2014).

[12] Section 5, Article 2 of the Law amending and supplementing a number of articles of tax laws (amending Article 13 of the Law on Personal Income Tax), section 9 Article 2 of Decree 12/2015/ND-CP on amending 
Article 16 Decree 65/2013/ND-CP of June 27, 2013; Point b, Clause 2, Article 11 of Circular 111/2013/TTBTC dated August 15, 2013 of the Ministry of Finance; Article 16 of Circular No. 92/2015/TT-BTC of June 15, 2015 of the Ministry of Finance and Official Letter No. 228/TCT-TNCN of January 21, 2015 of the General Department of Taxation on securities transfer.

[13] Bui Thi Thuy Linh (2014). The comparison of the laws on corporate income tax in Vietnam and Japan. Faculty of Law, Hanoi National University, 59-60.

[14] Nguyen Thanh Hung (2016). Corporate income tax policies for real estate: situation and solutions. Journal of Finance, 46-48.

[15] Pham Thi Kim Anh (2019). Theoretical and practical basis for building property tax in Vietnam. Journal of Finance, 9-11. 